\title{
Surgical Alloplastic Approach with Dual Mesh in a Multisacular, Recurrent Incisional Hernia - Case Presentation
}

\author{
Daniel MIHALACHE ${ }^{1}$, Bogdan SOCEA ${ }^{2 *}$, Alexandru SMARANDA², Anca NICA², Ovidiu Gabriel BRATU³, \\ Alexandru Constantin CARAP ${ }^{2}$, Cezar MOCULESCU², Dumitru Cristinel BADIU ${ }^{5}$, Dan Nicolae \\ PĂDURARU ${ }^{6}$, Mihai DIMITRIU7, Vlad Denis CONSTANTIN²
}

\begin{abstract}
Repairing an incisional ventral hernia represents a challenge for the surgeon. The high recurrence rates observed during hernia repair by tissue approximation leads to development of tension-free procedures by using prosthetic materials. Incisional or ventral hernia is a very common multifactorial pathology that requires surgical intervention to prevent complications, such as pain, discomfort, bowel obstruction or strangulation. To perform the wall repair it is of utmost importance to understand the pathogenesis of the hernia, the anatomy and physiology of the abdominal wall, and surgical techniques. Several repair methods are available, including open suture repair, open mesh repair, the component separation technique, and tissue expansion assisted closure. To perform the ventral hernia repair properly, a full understanding and correct selection of mesh and management of probable complications, such as seroma, bowel injury, enteric fistulae, and recurrence, is essential.

There are lots of scientific debates about an ideal material for mesh parietal repair. In latest years, the tendency is that the continuous decreasing territory of polyester mesh to be slowly replaced by the increasing territory of polypropylene mesh in open procedures for abdominal incisional hernia repair.

The goals of incisional hernia repair are the prevention of visceral eventration, incorporation of the abdominal wall in the repair, provision of dynamic muscular support, and restoration of abdominal wall continuity in a tension-free manner.
\end{abstract}

\footnotetext{
1 Surgical Department, County Emergency Hospital, Ploiesti, Romania

${ }^{2}$ Department of Surgery, "Sf. Pantelimon" Emergency Clinical Hospital, „Carol Davila" University of Medicine and Pharmacy, Bucharest, Romania

${ }^{3}$ Department of Urology, Central Clinical Military Hospital, „Carol

Davila" University of Medicine and Pharmacy, Bucharest,

Romania

${ }^{4}$ Department of Plastic Surgery and Reconstructive Microsurgery, Emergency Clinical Hospital, „Carol Davila" University of Medicine and Pharmacy, Bucharest, Romania

${ }^{5}$ Department of Surgery, "Bagdasar-Arseni" Emergency Clinical Hospital, "Carol Davila" University of Medicine and Pharmacy, Bucharest, Romania

${ }^{6}$ Department of Surgery, Emergency University Hospital, „Carol Davila" University of Medicine and Pharmacy, Bucharest, Romania

${ }^{7}$ Department of Obstetrics and Gynecology, "Sf. Pantelimon” Emergency Clinical Hospital, „Carol Davila" University of Medicine and Pharmacy, Bucharest, Romania
}

\section{Corresponding author.}

Bogdan SOCEA, Department of Surgery, "Sf. Pantelimon"

Emergency Clinical Hospital, „Carol Davila" University of Medicine and Pharmacy, Bucharest, Romania.

E-mail: bogdansocea@gmail.com 
We present the case of a 55 years old woman who had a history of multiple surgical interventions. We performed an open surgical approach, tension free technique using an intraperitoneal dual-mesh.

Keywords: dual mesh, recurrence, incisional hernia.

\section{Rezumat}

Repararea unui defect parietal abdominal reprezintă o provocare pentru chirurg. Ratele mari de recidivă observate în timpul procedeelor tisulare au condus la dezvoltarea de procedee fără tensiune în țesuturi (tension free) prin utilizarea de materiale protetice. Hernia incizională sau ventrală este o patologie multifactorială foarte frecventă care necesită intervenție chirurgicală pentru a preveni complicațiile, cum ar fi durerea, disconfortul, obstrucția intestinală sau strangularea. Pentru a efectua reparația peretelui este extrem de important să înțelegem patogeneza herniei, anatomia și fiziologia peretelui abdominal și tehnicile chirurgicale. Sunt disponibile mai multe metode chirurgicale, inclusiv sutura țesuturilor prin metoda deschisă, aloplastia prin metoda deschisă, tehnica de separare a componentelor și închiderea asistată cu plastii tisulare. Pentru a efectua corect cura herniei ventrale, este esențială o înțelegere completă și o selecție corectă plaselor cu ochiuri de diferite dimensiuni și gestionarea complicațiilor probabile, cum ar fi seromul, leziunea intestinală, fistulele enterice și recidiva.

Există o mulțime de dezbateri științifice privind un posibil material ideal pentru repararea defectelor parietale. În ultimii ani, tendința în proceele deschise este ca locul ocupat de plasele de poliester cu ochiuri de dimensiuni în scădere, să fie încet înlocuit de plasele de polipropilenă cu ochiuri în creștere dimensională.

Obiectivele curei herniei incizionale sunt prevenirea evenimentelor viscerale, încorporarea peretelui abdominal în structura de rezistență, asigurarea unui suport muscular dinamic și refacerea continuității peretelui abdominal întro manieră fără tensiune.

Prezentăm cazul unei femei în vârstă de 55 de ani care a avut antecedente de intervenții chirurgicale multiple. Am efectuat o abordare chirurgicală deschisă, o tehnică fără tensiune, folosind o plasă dual-mesh intraperitoneală.

Cuvinte cheie: dual-mesh, recidivă, hernie incizională.

\section{INTRODUCTION}

Incisional hernia is defined as an abdominal wall defect at the site of abdominal wall closure and more than $10 \%$ of patients who undergo laparotomy, experience the hernia ${ }^{1}$. Ventral hernia is represented by a bulge of tissues through a weakness within abdominal wall muscles without surgery. There is an ongoing discussion concerning which factor contributes to such situations; if there is a 'hernia disease' or simply the coincidence of several conditions or even a physiological reaction to tensile forces stretching the abdominal wall ${ }^{2}$. Predisposing factors are obesity, diabetes, emergency surgery, postoperative wound dehiscence or infection, smoking, immunosuppression, prostatism, and collagen disorders such as abdominal aortic aneurysm and Ehlers-Danlos Syndrome ${ }^{3,4}$. Mesh reinforcement is generally considered the standard of care in hernia repair. Infection is a common complication following hernia repair. Infection of the mesh is a complex problem. Knowledge of new treatment strategies is necessary for surgeons performing abdominal wall reconstruction ${ }^{5}$.
It involves excision of the hernia sac and identification of healthy fascial margin. For bridging the fascial defect, polypropylene mesh anchors to all adjacent tissues and has the propensity for inducing extensive adhesions to viscera if placed in a position where they become adjacent to bowel in this technique. Erosion of the mesh may then occur into the intestine, so it is recommended to use an expensive double-layered mesh with an inner layer with non-adhesive coating. As these meshes do not restore the anatomy and physiology of the anterior abdominal wall, activities that increase intra-abdominal pressure impact significant tension on the mesh-fascial interface, which is the weakest point of the repair. The recurrence rate of this technique tends to be higher than those of the underlay and inlay technique $^{6,7}$. Different types of mesh have been studied to find an ideal alloplastic material for reinforcement ${ }^{8-10}$. The advantages and disadvantages of each material could not reveal an ideal material for herniorafia.

The choice of mesh is made according to the location and type of hernia, the presence or not of the septic 


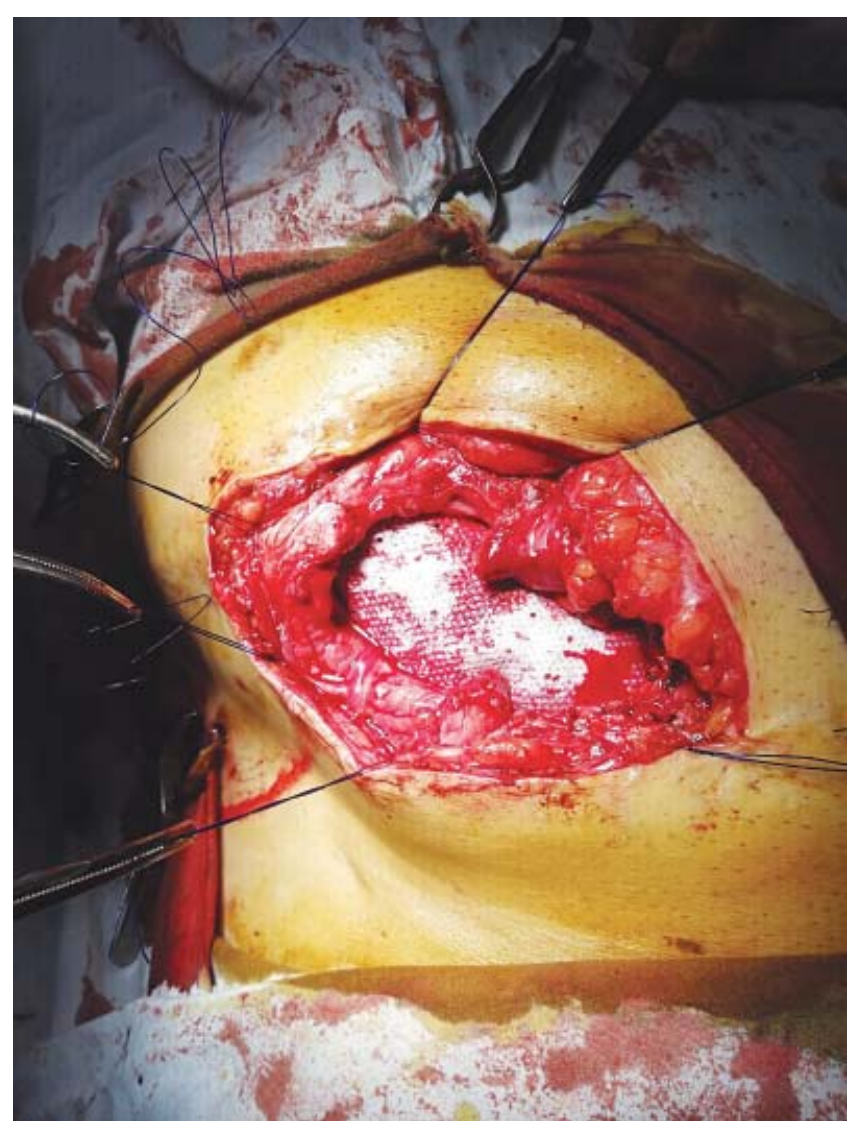

Figure 1. The placement of the dual mesh and its fixing through the abdominal wall with separate non resorbable suture.

factor, the surgeon's preferences, and other considera$\operatorname{tion}^{11,12}$.

\section{CASE PRESENTATION AND DISCUSSIONS}

We present the case of a 55 years old woman who came to our emergency room accusing pain in her lower abdomen, nausea, and fever. The patient had a history of multiple surgical interventions such as: umbilical hernia (mesh free), ventral hernia after mesh free repair and one surgical approach for mesh infection. Clinical exam revealed an enlarged abdomen, an abdominal wall defect that was almost incarcerated and red skin erythema near the umbilical region. The patient had associated pathologies that did not allow us to operate immediately after admission; atrial fibrillation, high blood pressure and type II diabetes also her body mass index was 30. Laboratory tests showed high glucose levels $310 \mathrm{~g} / \mathrm{dl}$, white blood cell count $18.000 \mathrm{mmc}$, INR of 2.6 and blood pressure was $170 / 90 \mathrm{mmHg}$; she was



Figure 2. Positioning the dual-mesh so as to assure the coverage of the whole wall defect with $3 \mathrm{~cm}$ on each side.

admitted in the intensive care unit for $48 \mathrm{~h}$ preoperative. We performed an open surgical approach, tension free technique using an intraperitoneal dual-mesh (Figure 1, Figure 2). Although she showed signs of intestinal obstruction and the adhesiolisis process was difficult, the small intestine was viable and no enterectomy was necessary.

Postoperatively the patient had a fast recovery, blood work was normal in the next 48 hours, her BP was stable and glucose levels also normal. Incision was almost healed after 7 days and no surgical site infection at discharge.

The patient had no recurrence in the next year as she returned for checkup.

Different recurrence rates have been reported for different types of nets ${ }^{13}$. As long as there is no ideal material for all situations, the surgeon is put in front of choosing the ideal material for the particular situation he is facing ${ }^{14,15}$. In large defects, various assistive techniques have been imagined to gain regarding the abdominal wall ${ }^{16}$. 


\section{CONCLUSIONS}

Regarding the advances in the understanding of the anatomy and physiology of the abdominal wall, the choice of suture materials, the understanding of closure techniques, and the continuous development of prosthetic materials, the management of incisional hernia continues to move forward. Incisional hernia repair is considered as a challenging procedure, especially in recurrent hernias, such as in our case, in which the chances of recurrence increases with each surgical technique. Successful repair relies on knowledge of the dynamics of the abdominal wall, thorough technical execution,

\section{References}

1. Chrysos E, Athanasakis E, Saridaki Z, Kafetzakis A, Dimitriadou D, Koutsoumpas V, Chalkiadakis G, Xynos E, Zoras O. Surgical repair of incisional ventral hernias: tension-free technique using prosthetic materials (expanded polytetrafluoroethylene GoreTex Dual Mesh). Am Surg. 2000 Jul;66(7):679-82.

2. Choi YB, Lee IS. Incisional and Ventral Hernia Repair. Journal of Minimally Invasive Surgery 2018;21(1):5-12.

3. van't, RM, De Vos Van Steenwijk, PJ, Bonjer, HJ, Steyerberg, EW, and Jeekel, J. Incisional hernia after repair of wound dehiscence: incidence and risk factors. Am Surg. 2004;70,281-286.

4. Luijendijk, RW, Hop, WC, and van den Tol, MP. A comparison of suture repair with mesh repair for incisional hernia. $N$ Engl J Med. 2000;343:392-398.

5. Tuveri M, Tuveri A, Nicolo E. Repair of large abdominal incisional hernia by reconstructing the midline and use of an onlay of biological material. Am J Surg. 2011;202:e7-11.

6. Millikan KW, Baptista M, Amin B, Deziel DJ, Doolas A. Intraperitoneal underlay ventral hernia repair utilizing bilayer expanded polytetrafluoroethylene and polypropylene mesh. Am Surg. 2003;69:287-291.

7. Mihalache DI, Socea B, Smaranda AC, Nica AA, Carap AC, Bratu OG, Stanescu AMA, Groseanu F, Dimitriu MCT, Constantin VD. Surgical approach of infected mesh with entero-atmospheric fistula - a case presentation. Arch Balk Med Union 2019;54(3):591-595. doi.org/10.31688/ABMU.2019.54.3.29.

8. Baleanu V, Georgescu I, Davitoiu D, Manda L, Socea B, TeneaCojan TS. Incisional hernia complications after using polypropylene mesh - case report. Research and Science Today 2018;Suppl. 1(15):126-133. appropriate selection of synthetic or bioprosthetic material, and constitution of the surgical team. Though laparoscopic repair has been demonstrated to be safe and a more resilient repair than open repair, open mesh repair remains a suitable alternative

Compliance with ethics requirements: The authors declare no conflict of interest regarding this article. The authors declare that all the procedures and experiments of this study respect the ethical standards in the Helsinki Declaration of 1975, as revised in 2008(5), as well as the national law. Informed consent was obtained from all the patients included in the study.

9. Socea B, Carap A, Bratu OG, et al. The role of the composite and biologic meshes in the trocar site hernia repair following laparoscopic surgery. Revista de Materiale Plastice 2018;55(2):146148.

10. Constantin VD, Socea B, Nica E, et al. A comparison between two types of textile meshes and the intra-abdominal pressure values after Rives-Stoppa incisional hernia repair. Industria Textila 2015; 66(2): 80-84

11. Socea B, Smaranda AC, Nica AA, et al. Spiegel hernia - case presentation. ArchBalk Med Union 2018;53(1):152-4.

12. Constantin V, Carap A, Bobic S, Albu M, Nica E, Socea B. Traumatic abdominal wall hernia associated with small bowel injury - case report. Indian J Surg 2015;77(Suppl 1):174-7.

13. Socea B, Socea LI, Bratu OG, et al. Recurrence rates and mesh shrinkage after polypropylene vs. polyester mesh hernia repair in complicated hernias. Revista de Materiale Plastice 2018;55(1):79-81.

14. Trandafir A, Vasile D, Davitoiu D, et al. The new self-gripping mesh and it's benefits in inguinal hernia repair - review of the literature. Research and Science Today 2018; 1(15): 132-139.

15. Constantin VD, Carap A, Socea B, Ficai A, Albu MG, PaunicaPanea $G$. The influence of synthetic material meshes on the surgical repair of abdominal wall defects. Romanian Journal of Materials 2015;45(3):290-297.

16. Socea B, Diaconu C, Bratu OG, et al. Postoperative outcome of a giant incisional hernia resolved by anterior component separation technique. Romanian Journal of Medical Practice 2018;XIII (4):268-70. 